\title{
EFFECTIVENESS OF HUMAN RESOURCES MANAGEMENT IN THE ENTERPRISES OF UKRAINE'S BAKERY INDUSTRY
}

\author{
Yaryna Yuryk1, Olena Bezpalko², Yuliia Hryniuk ${ }^{3}$ \\ ${ }^{I}$ PhD in Economics, Senior Researcher, Institute of Economics and Forecasting of the National Academy of Sciences of \\ Ukraine, Address: 26, Panasa Myrnoho, Kyiv, Ukraine. Tel.: +38 (097) 92047 42, E-mail: yarina79@ukr.net \\ ${ }^{2}$ PhD in Economics, Docent. National University of Food Technologies. Address: 68 Volodymyrska str., 01601 Kyiv, \\ Ukraine. Tel.: +38 (066) 25475 93, E-mail: bezpalko.elen@gmail.com
}

${ }^{3}$ Senior Lecturer. National University of Food Technologies. 68 Volodymyrska str., 01601 Kyiv, Ukraine. Tel.: +38(093) 87597 20,E-mail: ulgrin@ukr.net

Received 2907 2020; Accepted 04112020

\begin{abstract}
Competition in the national labor market, which is strengthening as globalization and structural employment disproportions intensify, encourages domestic companies to seek reserves for more effective human resource management as the only competitive advantage that cannot be copied. The aim of the research is to develop a comprehensive methodology for assessing the effectiveness of HR management at bakery companies as employers of a Ukraine's priority industry, which is based on the provisions of the new (first) international human capital accounting standard ISO 30414:2018 and is implemented using system-structural, abstract-logical methods, as well as those of multidimensional statistical analysis and visualization of empirical data. The developed methodology will allow to determine an integrated indicator for the effectiveness of HR-management, which simultaneously performs the functions of controller and navigator of strategic management decisions in this area.
\end{abstract}

Keywords: effectiveness, integrated indicator, complex methodology, HR-metrics, taxonomy, human resources management.

JEL Codes: J8, J53, M54.

\section{Introduction}

In the near future, Ukraine's demographic forecast is quite pessimistic. This country is among the ten countries with the highest rates of depopulation and projected population decline (by $7.1 \%$ by 2030 and by $19.9 \%$ by 2050) (United Nations, 2019). According to Ptoukha Institute of Demography and Social Studies of the National Academy of Sciences of Ukraine (2014), the contingent of Ukrainian citizens in working age $(20-59$ years) in relation to those of pension age (60 and older) will decrease from 2.45 in 2019 to 2.03 in 2030 and 1.46 in 2050, which is evidence of the nation's ageing.

The negative effects of external labor migration are felt. In 2018, Ukrainians received the largest number of residence permits in the EU among its non-residents (526.8 thousand, that is, $16.3 \%$ of the total number of permits, of which $64.7 \%$ are work visas) (Eurostat, 2019), while the scale of illegal employment labor migrants from Ukraine is difficult to estimate even approximately.

Further visa liberalization for migrants from Eastern Europe by a number of Western European countries, is aimed at their longer stay in the destination country, and introduction of incentive mechanisms for employment of highly skilled specialists such as Blue Card, will intensify the outflow of labor in both white and blue collars groups. The lack of labor supply of the latter is formed, among other things, due to the low prestige of working (technical) professions and low quality of training in vocational education institutions.

Copyright (C) 2021 Author(s), published by Vytautas Magnus University. This is an open access article distributed under the terms of the Creative Commons Attribution Non-Commercial 4.0 (CC BY-NC 4.0) license, which permits unrestricted use, distribution, and reproduction in any medium provided the original author and source are credited. The material cannot be used for commercial purposes. 
Therefore, all Ukrainian industrial companies will soon face a staff shortage. Although since 2005, Ukraine's industry has already reduced employment by more than $40 \%$ (State Statistics Service of Ukraine, 2020), losing its leading position in the ranking of this country's employment by economic activity (now it ranks 3rd). Attention is drawn to the state of the labor market in socio-strategic industries, which include food processing and, in particular, baking as a core segment of food security. In Ukraine, every third employed "food grower" works here, which corresponds to European trends: the average share of employed in the bakery industry of the EU countries is now $33 \%$, being, in most of them, the dominant field of employment in the industrial complex (Food Drink Europe, 2019). The shortage of human resources (being, among other things, carriers of intellectual capital) slows down the innovative restructuring, whose slow pace threatens Ukrainian bakeries with bankruptcy, and the country - with structural unemployment and food crisis due to stagnation in the industry. This forces them, already now, to look for effective ways (technologies) to attract candidates, retain and make optimal use of the existing personnel, which can be found only via assessing the current state of HR management in order to provide reliable and predictive information about its weaknesses and reserves to improve its effectiveness.

Therefore, the purpose of the research is to develop adaptive methodological tools for comprehensive assessment of the effectiveness of human resources management as the company's ability to obtain from all its HR-processes (services, programs) the desired (planned) effects and / or results that can be measured. So the object of research is the effectiveness of human resources management in Ukraine's bakery industry, which considers, in the methodology of its assessment, both sectoral and intracompany specifics.

In Western scientific circles over the past half century, a number of methodological approaches have been developed to assess the effectiveness of HR-management, which we have summarized in the following categories:

- the profit based one, whose emergence is associated with a shift in the focus of research on the system of human resources management towards considering it a cost and, accordingly, an object of management saving. In this case, the system of human resources management is taken as an investment that tends to rise, being its feasibility measured in terms of return on investment (Becker, 1975, p. 9-49; Fitz-enz, 2010; Phillips et al., 2016). HR(Capital)ROI can be determined and compared in terms of individual HR-processes (projects), parts of the company's organizational structure or even a ROI in its other assets. Currently, its value has become a key measure of the effectiveness of HR management of a large number of companies, including the Fortune Global 500 [ING Group Annual Report, 2019], countries [PricewaterhouseCoopers, 2014] and geographical regions [Viljoen, 2012], and remains universal HR metrics in global research [Deloitte Global Human Capital Trends, 2020];

- the cost oriented one, developed within the eponymous management model, according to which human resources (capital) began to be considered as a source of companies' capitalization, while the effectiveness of management decisions applied to them began to be assessed in terms of economic added (market) value (HEVA, HCVA, HCMV) (Fitzenz, 2000; Scarbrough, Elias, 2004). This measure satisfies the financial interests of owners and shareholders better than does the accounting profit (used in the previous approach). From time to time, alternative formulas for calculating these indicators appear (the same is observed with HR(C)ROI, such as its transformation into the format Vienna Index [Dibernardino, 2015]), which are used either as stand-alone methodologies, or as part of the system of key performance indicators (KPIs) or as HR-metrics, which will be discussed below;

- the stakeholder (expert) one, which became a projection of the concept of stakeholders and business ethics (Freeman, 1984) on the HRM area, and whose 
effectiveness is measured via expert methods of the company's internal stakeholders (Ulrich, 1989; Mitchell et al., 1997; Greenwood, 2002), among which became widespread interview, focus group and employee survey methods [Carter et al., IES, 2011; Armstrong, Taylor, 2014], Analytical Hierarchy Process (AHP) technique [Quang et al., 2020], 360-degree feedback [Society for Human Resource Management, 2017]. Within this approach also, there is an option to assess consumer expectations and customer (external stakeholders') feedback (Schneider, White, 2004), because HR-management directly affects the quality, range, price and level of service, that is, all that shapes customer loyalty, which generates additional income. For its implementation in the service company SHRM specialists propose to use the method of "mystery shoppers" [Society for Human Resources Management, 2017];

- the comprehensive (balanced) one. First, it includes methods to analyze the effectiveness of human resource management, based on the theory of management by objectives (MBO) by Drucker (1954), which linked the goals of HRM with companies' business strategy and created the preconditions for measuring and monitoring their achievement in terms of KRIs. They involve building a modified version of the Kaplan and Norton balanced scorecard (1996) - the HR Scorecard, which eliminated the shortcoming of the original model, which reduced HRanalysis to only one functional unit - learning $\&$ growth, and covered a wide range of HR functions in all classic BSC blocks (Fitz-enz, 2000; Becker et al., 2001; Huselid, Barnes, 2003). Today HR-metric scorecards have a lot of interpretations performed by both network consulting companies [Deloitte, 2016] and representatives of the scientific community from around the world [Gabanova, 2012; Boudlaie, 2020 and others]. Secondly, these are methods of comprehensive assessment of the effectiveness of HR-management, which contain the author's interpretation of the content of HR-metrics, methods of their statistical processing and establishment of predicative or causal relationships with performance indicators of other subsystems of company management, whose choice depends on the tasks formulated for the analysts;

- the benchmarking one, which appeared in response to the acceleration of economic integration and the demands of highly competitive markets for the comparison between their players' HRM effectiveness in order to focus on the leader. The first global experiments in this direction were conducted by the Saratoga Institute (in 2003 became a division of PricewaterhouseCoopers) together with the Society for Human Resource Management (Fitz-enz, 1995) based on 30 HR-metrics developed by Fitz-enz earlier (Fitz-enz, 1984). Now these are two separate analytical systems with several hundred such metrics, which are combined at the request of customers. Other consulting companies (Big Four accounting firms, Mercer) and professional associations (International Public Management Association for HR, Society for Human Resource Management, Chartered Institute of Personnel Development etc.) also offer their own HR-benchmarking projects ${ }^{1}$.

Despite numerous trials and significant scientific and considerable practical results obtained using these approaches, each of them has obvious shortcomings. The profit based monoapproach reduces the analysis of the effectiveness of human resources management to the components of the numerator and denominator of their ROI. Another difficulty lies in the separation of

${ }^{1}$ At the moment, extracts from reports up to and including 2019 are posted on the websites of these organizations (free access), and full-scale benchmarking research can be ordered on a paid basis.

Copyright (C) 2021 Author(s), published by Vytautas Magnus University. This is an open access article distributed under the terms of the Creative Commons Attribution Non-Commercial 4.0 (CC BY-NC 4.0) license, which permits unrestricted use, distribution, and reproduction in any medium provided the original author and source are credited. The material cannot be used for commercial purposes. 
direct and associated costs of HRM initiatives, the failure of accounting profits (numerator in the formula) to reflect all risks to investors and the inability to clearly identify that its part which arises due to investments in human resources. The cost oriented approach too is a mono-approach, but here appear additional problems with the correctness of the assessment and adjustment of the components of the EVA indicator (MVA). The stakeholder (expert) approach is characterized by the subjectivity of assessments and the likelihood of reducing their reliability due to the incompetence of experts and respondents, and due to disregard or intersection of the interests of certain groups of stakeholders. Access to HR benchmarking services for many Ukrainian companies, including bakeries, is nearly closed due to high cost, as well as due to the poorly developed infrastructure for the exchange in data and experience between market participants and the low level of information security in the current legislation, which provokes the companies' fear for information disclosure. The balanced approach based on HR Scorecard requires a well-established practice of human resource management by KPIs, which limits its application in companies where it is absent.

Among the methods of comprehensive assessment of the effectiveness of HRmanagement by Ukrainian authors, most are reduced to grouping HR-indicators by functional principle or types of effectiveness (social, economic, organizational) and advice on monitoring their values in dynamics, and less often they represent sophisticated methods with justification of the mechanism for the selection of partial indicators (based on the same functional principle), their synthesis into the integral one, testing on companies in a certain branch of Ukrainian industry and provision of recommendations (Bolotova, 2019; Dovgan et al., 2015, p. 89106; Shvets, Kovalenko, 2013, p. 64-75). These shortcomings in the methodological support for assessing the effectiveness of human resources management become extremely noticeable in the face of the approaching staff default and their increasing role as drivers of innovative economy and socio-economic transformations, and therefore require qualitatively new approaches.

\section{Research methodology}

Operating the abstract-logical method (in the formation of HR-metrics), methods of multidimensional statistical analysis, in particular, the metric method of classification, taxonomy (for integrated metric convolution), tabular-graphic (for visualization of empirical data) and abstract-logical ones (for descriptive statistics and specification of management decisions), we present a methodological algorithm for comprehensive assessment of the effectiveness of company HRmanagement, which is presented in steps below.

Step 1. Selection of HR-metrics and methods of their aggregation. As is established, a popular way to select indicators in existing methods is selecting them by HR management functions. As the management systems of modern companies become more complex, the number of such functions naturally increases (in the work of Armstrong and Taylor (2014) there are as many as 25 of them, although traditionally their number varies within 10-15). This increases the variability of their choice by analysts, which is positive from the point of view of implementation of the principle of complexity in assessment, but may hinder its objectivity due to the "bloated" or, conversely, too narrow list. At the same time, some methods are overloaded with an excessive number of indicators representing these functions, leading to a loss of useful information. For example, developers of the BSC methodology emphasize that the effectiveness indicators should not exceed 20 (Kaplan, Norton, 1996).

Guided by the intention to unify the criterion for the distribution of indicators to assess effectiveness of HR management by content-related groups and their assignment to each of them, the authors used the provisions of the international quality standard ISO 30414: 2018 "Human resource management Guidelines for internal and external human 
capital reporting" (Organisation Internationale de Normalisation, ISO, 2018) - the first one in the context of accounting for exactly the human resources and their contribution to business effectiveness. Thanks to this it was possible to create a holistic system of HRmetrics, whose structure includes 11 HRM- areas and 15 indicators (Table 1) selected according to the guidelines of this standard and taking into account the peculiarities of personnel management and administration of Ukraine's industrial companies.

\section{Table 1. Metrics for assessing the effectiveness of human resource management} (Source: developed by the authors)

\begin{tabular}{|c|c|c|c|}
\hline № & HRM areas & Indicators-representatives & Legend \\
\hline 1 & Compliance and ethics & Share of effectively solved collective labor disputes in total, $\%$ & $\mathrm{~S}_{\text {escld }}$ \\
\hline \multirow{2}{*}{2} & \multirow{2}{*}{ Costs } & Share of labor costs in total operational costs, $\%$ & $\mathrm{~S}_{\mathrm{lc}}$ \\
\hline & & Ratio of company average wage to sectoral average wage, $\%$ & $\mathrm{R}_{\mathrm{aw}}$ \\
\hline 3 & Diversity & Level of vertical gender segregation, p.p. & $\mathrm{L}_{\mathrm{vgs}}$ \\
\hline \multirow{2}{*}{4} & \multirow{2}{*}{ Leadership } & Rate of effectiveness of manager training, $\%$ & $\mathrm{R}_{\mathrm{emt}}$ \\
\hline & & Share of tutors in total personnel, $\%$ & $\mathrm{~S}_{\mathrm{t}}$ \\
\hline 5 & Organizational culture & Personnel loyalty rate, $\%$ & $\mathrm{R}_{\mathrm{pl}}$ \\
\hline 6 & $\begin{array}{l}\text { Organizational health, } \\
\text { safety and well-being }\end{array}$ & $\begin{array}{l}\text { Integral indicator of labor severity (according to the methodology of the } \\
\text { Research Institute of Labor and Employment of the Ministry of Social } \\
\text { Policy and the National Academy of Sciences of Ukraine), points }\end{array}$ & $\mathrm{I}_{\mathrm{ls}}$ \\
\hline 7 & Productivity & Personnel profitability, ths Hrn & $\mathrm{P}_{\mathrm{p}}$ \\
\hline \multirow{2}{*}{8} & \multirow{2}{*}{$\begin{array}{l}\text { Recruitment, mobility and } \\
\text { turnover }\end{array}$} & Total personnel movement rate, $\%$ & $\mathrm{R}_{\mathrm{tpm}}$ \\
\hline & & Staff turnover rate, $\%$ & $\mathrm{R}_{\mathrm{st}}$ \\
\hline 9 & Skills and capabilities & Share of personnel involved in professional training in total personnel, $\%$ & $\mathrm{~S}_{\mathrm{ppt}}$ \\
\hline 10 & Succession planning & Career growth rate, $\%$ & $\mathrm{R}_{\mathrm{cg}}$ \\
\hline \multirow{2}{*}{11} & \multirow{2}{*}{ Workforce availability } & Absenteeism rate, $\%$ & $\mathrm{R}_{\mathrm{a}}$ \\
\hline & & Staffing ratio, $\%$ & SR \\
\hline
\end{tabular}

For the complete reduction of a significant number of indicators from Table. 1 , the taxonomic method proposed by the Polish scientists Hellwig and Pluta is chosen, on whose authentic materials (Hellwig, 1968; Pluta, 1979) we will rely further, adapting them to the needs of the research.

Arguments in favor of taxonomy as one of the most acceptable methods of convolution of the input data set by measuring the distance between them as points in multidimensional space and an artificially constructed reference point lie in the capabilities of its mathematical apparatus: reduction of quantitative and/or qualitative indicators with different dimensions to dimensionless values (standardization); their weighting on hierarchical coefficients of importance by statistical reception of "critical distances", avoiding, at will, the method of expert estimations; and linear ordering of multi-vector - in the direction of their influence (incentive/disincentive) on the object of study - indicators into a single integral. All this, in the end, will provide a clear idea of the effectiveness of HR-management of a particular company or set of companies and the ability to rank them, which is preceded by the following steps.

Step 2. Formation of a matrix of observations of the form $X=\left\|x_{i j}\right\|$,

where $i$ is the ordinal number of the period $(\mathrm{i}=\overline{1, n}) ; \mathrm{j}-$ HR-metrics from

Copyright (C) 2021 Author(s), published by Vytautas Magnus University. This is an open access article distributed under the terms of the Creative Commons Attribution Non-Commercial 4.0 (CC BY-NC 4.0) license, which permits unrestricted use, distribution, and reproduction in any medium provided the original author and source are credited. The material cannot be used for commercial purposes. 
Table $1(j=\overline{1, m}) ; \mathrm{x}_{\mathrm{ij}}$ - value of the $\mathrm{j}$-th HR-metric in the $\mathrm{i}$-th period.

Step 3. Formation of a matrix of standardized values of HR-metrics of the form $Z=\left\|z_{i j}\right\|$,

where $z_{i j}$ is the value of the $\mathrm{j}$-th HRmetric in the $i$-th period after the standardization procedure by the formula:

$$
z_{i j}=\left(x_{i j}-\bar{x}_{j}\right) \div \sigma_{j}
$$

where $\overline{x_{j}}$ is average value of the $\mathrm{j}$-th HR-metric; and $\sigma_{j}-$ its standard square deviation.

Step 4. Adjustment of standardized values of HR-metrics by the hierarchy coefficients. Standardization in the third step equalizes the variances of the output data and nullifies their average values, i.e. standardized HR-metrics become equilibrium relative to the taxonomic distance, and their significance is leveled. This can be corrected by entering the hierarchy coefficients according by the following scheme:

- transpose matrix of standardized HR-metrics into a matrix of the form $Z^{T}=\left\|z_{j i}\right\| ;$

- convert it into a symmetric matrix of distances between the indicators $\mathrm{C}=\left\|\mathrm{c}_{r s}\right\|$, each element of which $\left(\mathrm{c}_{\mathrm{rs}}\right)$ is calculated by the formula of Euclidean distance:

$$
c_{r s}=\sqrt{\sum_{i=1}^{n}\left(z_{i r}-z_{i s}\right)^{2}}
$$

where $r$ and $s$ are specific numbers of indicators according to the column and row of the distance matrix $(r, s=\overline{1, m})$.

- find the critical distance between adjacent indicators as the maximum of the minimum in the column (row) of matrix $\mathrm{C}$ (interpolation by the method of "nearest neighbor"):

$$
\mathrm{c}_{\text {critical }}=\max _{r} \min _{s} c_{r s}
$$

- $\quad$ summarize, for each indicator, all distances that do not exceed the critical one:

$$
\omega_{j}=\sum_{s=1}^{m} c_{j s}, \text { where } c_{j s} \leq c_{\text {critical }}
$$

- select the indicator with the highest sum of distances and determine the hierarchy coefficient $\left(\mathrm{W}_{\mathrm{j}}\right)$ by the formula:

$W_{j}=\omega_{j} \div \omega_{\max }$, where $\omega_{\max }=\max _{j} \omega_{j}$

Here (5) the coefficients of the hierarchy are not identical to the coefficients of weight in the traditional sense, i.e. the sum for all indicators is not equal to one, and their values are the higher (more important), the greater the sum of the distances of a single indicator from the other neighboring ones (the most important indicator will have $\mathrm{W}_{\mathrm{j}}=1$ );

- weigh the standardized values of HR-metrics on the hierarchy coefficient:

$$
z_{i j}^{\prime}=z_{i j} \times W_{j}
$$

Note that often in the literature on the assessment of economic phenomena and processes with the taxonomic method, Step 4 does not appear at all (which distorts the final data) or is replaced with expert methods of the analysis of weight coefficients that have a different meaning.

Step 5. Differentiation of HR-metrics and construction of the reference vector. All weighted standardized values of indicators $\left(z_{i j}^{\prime}\right)$ are distributed according to the direction of influence on the resulting indicator (in our case - the effectiveness of human resources management in the company): positive (incentive) and negative (disincentive). Among the HR-metrics in Table 1, four indicators are disincentives (level of vertical gender segregation, integrated indicator of labor 
severity, staff turnover rates and absenteeism), others - incentives. This division is based on the construction of the reference vector as a point $\mathrm{P}_{0}$ with coordinates $\left(z_{01}^{\prime}, z_{02}^{\prime}, \ldots, z_{0 m}^{\prime}\right)$, which are: for the incentive indicator - the maximum among its weighted standardized values for the whole analyzed, and for the disincentive one - the minimum.

Step 6. Calculation of the taxonomic (integrated) indicator as that of the effectiveness of human resource management (I $\left.\mathrm{I}_{\text {ehrm}}\right)$ by the formula:

$$
\mathrm{I}_{e h r m}=1-d_{i}=1-\mathrm{c}_{\mathrm{i} 0} \div \mathrm{c}_{0}
$$

where $d_{i}$ is intermediate taxonomic indicator in the $\mathrm{i}$-th period $\left(d_{i} \in[0 ; 1]\right)$; $\mathrm{c}_{\mathrm{i} 0}$ is the Euclidean distance between the weighted standardized values of the indicators in the i-th period and in the reference vector; and $\mathrm{c}_{0}-$ the maximum possible distance from the consolidated standard, which is found by the rule of "three-sigma":

$$
\mathrm{c}_{0}=\overline{\mathrm{c}}_{0}+3 \times \sigma_{0}
$$

where $\overline{\mathrm{C}}_{0}$ is the arithmetic mean for all $\mathrm{c}_{\mathrm{i} 0}$; and $\sigma_{0}-$ their standard deviation.

Step 7. Economic interpretation of the taxonomic (integrated) indicator of the effectiveness of HR-management in a company and the development of adequate situations of managerial decisions to improve it. The value of the taxonomic indicator varies from 0 to 1 (the optimum is approximation to 1 , which indicates a qualitative increase in the characteristics of the object of study). We graduated its ranges by the enlarged Harrington Desirability Scale (1965), whose segments are adjusted according to the law of normal distribution of random variables, when integral estimate will fall into each of them with equal probability. We formulated quantitative-linguistic evaluation scale and strategic management settings for manufacturing companies for each numerical range of values $\mathrm{I}_{\text {ehrm: }}$ :

$$
\mathrm{I}_{\text {ehrm }} \in[0 ; 0.36] \quad-\quad \text { low }
$$

effectiveness (anti-crisis HR-strategy): initiation of personnel audit of all HRM-areas and rehabilitation (on its basis) of human resources, formation of the preventive culture of "economical production" and labor protection, optimization of quantitative and qualitative staff, efforts to enhance involvement and motivation of the companies' core personnel;

$$
\mathrm{I}_{\text {ehrm }} \in(0.36 ; 0.64] \text { - medium }
$$

effectiveness (HRM-focusing strategy): selective personnel audit of problematic HRM-areas, and "surgical" investments in them, introduction of advanced personnel technologies and full-fledged HR-analytics (talent analytics);

$$
\mathrm{I}_{\text {ehrm }} \in(0.64 ; 1] \quad-\quad \text { high }
$$

effectiveness (strategy to strengthen the position on the labor market): increasing investment in the development of human resources, organizational culture and employer's brand, encouraging the personnel to innovate, and, in HR-analytics - emphasis on technologies of competitive analysis (forecasting) of the condition of labor market.

Along with the value of $\mathrm{I}_{\text {ehrm }}$ it is appropriate to investigate the dynamics and duration of its stay in a given interval, which reflects the direction (consistent or fragmentary) of the company' management efforts to ensure its sustainable growth and success of the measures taken.

\section{Research results}

The above methodological approach to comprehensive assessment of the effectiveness of human resources management was tested on the basis of three

Copyright (C) 2021 Author(s), published by Vytautas Magnus University. This is an open access article distributed under the terms of the Creative Commons Attribution Non-Commercial 4.0 (CC BY-NC 4.0) license, which permits unrestricted use, distribution, and reproduction in any medium provided the original author and source are credited. The material cannot be used for commercial purposes. 
leading employers in Ukraine's bakery sector - PJSC "Kyivkhlib" (the oldest producer in the sector, operating since 1930), LLC "First Capital Bakery" (commissioned by the holding "Bread" in 2012 ) and PJSC "Concern Khlibprom" (in operation since 2003 and a leader in the market of bread and bakery products of Western Ukraine, the holding company is OKKO Group), which geographically cover the labor market of the city of Kyiv, and Kyiv and Lviv regions. The assessment was carried out based on public financial accounting (SMIDA, 2020), statistical reports on labor and intra-company accounting on social and labor relations for 2016-2019, which were used to calculate 15 HR-metrics from Table. 1.

The evaluation results are summarized and presented in Table 2, according to which the priority indicator series differs as follows: in PJSC "Kyivkhlib", the first position in the company's hierarchical structure, i.e. the highest individual importance in the system of human resources management, is occupied by the ratio of average intra-company to sectoral (HRM area "Costs"); the same applies to PJSC Concern Khlibprom; in LLC First Capital Bakery, on the first position is coefficient of the effectiveness of management training (HRM area "Leadership"), while in PJSC "Concern Khlibprom", this indicator is the least significant, as it has weak links with other HR-metrics in their system.

Assigning to the standardized values of the indicators the corresponding coefficients of the hierarchy $\mathrm{Wj}$, for each of them the maximum (for incentives) and minimum (for disincentives) for 4 years values were chosen, which became the coordinates of the reference vector. A large number of benchmarks in a given year, for example, in PJSC "Kyivkhlib" is 2016, and in LLC "First Capital Bakery" - 2019, is only evidence of the achievement of these indicators the best values among other years, rather than high effectiveness HRmanagement. The probability of such an erroneous conclusion, we believe, is in some other methods, where the integrated indicator is formed by additive or multiplicative convolution of normalized values of indicators weighted by weights or without, or their simple ranking, which once again confirms the correctness of methodological choice.

Table. 2 presents a matrix of distances of indicators to their standards, whose yearly sum, as we see, the smaller, the closer they are. However, the value of $\mathrm{c}_{\mathrm{i} 0}$ does not unambiguously fix the degree of their similarity (distance). To do this, it is standardized by the maximum possible distance $c_{0}$ (penultimate column of Table 2), which, with a probability of $99.72 \%$, under normal distribution, is not exceeded by the random value of $\mathrm{c}_{\mathrm{i} 0}$ and at the output is an intermediate taxonomic indicator (last column of Table 2). 


\section{S sciendo}

Management Theory and Studies for Rural Business and Infrastructure Development

eISSN 2345-0355. 2021. Vol. 43. No. 1: 137-150

Article DOI: https://doi.org/10.15544/mts.2021.12

Table 2. Results of the adjusting of standardized values of HR-metrics by hierarchy ratios, construction of the reference vector and calculation of the degree of their similarity in a sample of Ukraine's bakery companies

\begin{tabular}{|c|c|c|c|c|c|c|c|c|c|c|c|c|c|c|c|c|c|c|c|}
\hline \multirow{5}{*}{ 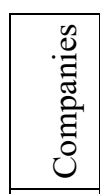 } & \multirow{2}{*}{\multicolumn{16}{|c|}{ HR-metrics (indicators) }} & \multirow[b]{3}{*}{$\mathrm{c}_{\mathrm{i} 0}$} & \multirow[b]{3}{*}{$\mathrm{c}_{0}$} & \\
\hline & & & & & & & & & & & & & & & & & & & \multirow[b]{2}{*}{$\mathrm{d}_{\mathrm{i}}$} \\
\hline & Tears & $\mathrm{S}_{\mathrm{escld}}$ & $\mathrm{S}_{\mathrm{lc}}$ & $\mathrm{R}_{\mathrm{aw}}$ & $\mathrm{L}_{\mathrm{vgs}}$ & $\mathrm{R}_{\mathrm{emt}}$ & $\mathrm{S}_{\mathrm{t}}$ & $\mathrm{R}_{\mathrm{pl}}$ & $\mathrm{I}_{\mathrm{ls}}$ & $\mathrm{P}_{\mathrm{p}}$ & $\mathrm{R}_{\mathrm{tpm}}$ & $\mathrm{R}_{\mathrm{st}}$ & $\mathrm{S}_{\mathrm{ppt}}$ & $\mathrm{R}_{\mathrm{cg}}$ & $\mathrm{R}_{\mathrm{a}}$ & SR & & & \\
\hline & $\mathrm{W}_{\mathrm{j}}$ & 0.305 & 0.416 & 1.000 & 0.334 & 0.338 & 0.183 & 0.460 & 0.198 & 0.414 & 0.638 & 0.630 & 0.091 & 0.091 & 0.268 & 0.494 & & & \\
\hline & & \multicolumn{15}{|c|}{ Matrix of standardized values of indicators $\left(\mathrm{z}_{\mathrm{ij}}\right)$ adjusted by hierarchy ratio $\left(\mathrm{W}_{\mathrm{j}}\right): Z^{\prime}=\left\|z_{i j}^{\prime}\right\|$} & & & \\
\hline \multirow{9}{*}{ 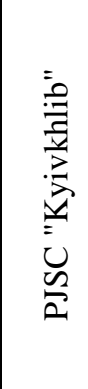 } & 2016 & 276 & -0.441 & 1.547 & -0.458 & -0.463 & 0.252 & $\mathbf{0 . 7 1 0}$ & 0.263 & 0.611 & -0.856 & -0.967 & 0.040 & 0.027 & 0.304 & 0.743 & & & \\
\hline & 2017 & 459 & -0.187 & 0.800 & -0.092 & -0.089 & -0.266 & -0.575 & 0.107 & 0.144 & -0.341 & -0.148 & -0.062 & -0.009 & & & & & \\
\hline & 2018 & .276 & 0.678 & -0.213 & 0.078 & 0.071 & 0.017 & -0.101 & -0.125 & -0.324 & 0.427 & 0.489 & -0.106 & -0.136 & 0.164 & 20 & & & \\
\hline & 2019 & .092 & -0.051 & 0.960 & 0.473 & 0.481 & -0.002 & -0.034 & -0.245 & -0.431 & 0.771 & 0.626 & 0.128 & 0.118 & -0.211 & & & & \\
\hline & & \multicolumn{15}{|c|}{ Matrix of distances between indicators $z_{i j}^{l}$ and reference vector } & & & \\
\hline & 2016 & .000 & 1.252 & 6.284 & 0.000 & 0.890 & 0.000 & 0.000 & 0.259 & 0.000 & 2.648 & 0.000 & 0.008 & 0.008 & 0.000 & 0.000 & 3.369 & \multirow{4}{*}{3.788} & 0.007 \\
\hline & 2017 & .540 & 0.749 & 0.026 & 0.133 & 0.324 & 0.268 & 1.651 & 0.124 & 0.218 & 1.237 & 0.672 & 0.036 & 0.016 & 0.429 & 0.465 & & & \\
\hline & 2018 & 0.000 & 0.000 & 1.377 & 0.286 & 0.168 & 0.055 & 0.659 & 0.014 & 0.874 & 0.118 & 2.122 & 0.055 & 0.064 & 0.219 & 1.858 & & & 0.741 \\
\hline & 2019 & 0.135 & 0.531 & 0.000 & 0.865 & 0.000 & 0.065 & 0.553 & 0.000 & 1.086 & 0.000 & 2.539 & 0.000 & 0.000 & 0.009 & 0.859 & & & \\
\hline \multirow{11}{*}{ 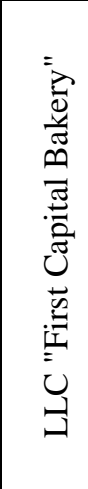 } & $\mathrm{W}_{\mathrm{j}}$ & 513 & 0.383 & 0.464 & 0.177 & 1.000 & 0.480 & 0.729 & 0.177 & 0.232 & 0.708 & 0.361 & 0.469 & 0.614 & 0.448 & 0.449 & & & \\
\hline & & \multicolumn{15}{|c|}{ Matrix of standardized values of indicators $\left(\mathrm{z}_{\mathrm{ij}}\right)$, adjusted by hierarchy ratio $\left(\mathrm{W}_{\mathrm{j}}\right): Z^{\prime}=\left\|z_{i j}^{\prime}\right\|$} & & & \\
\hline & 2016 & 762 & 0.470 & -0.753 & 0.220 & -0.887 & -0.532 & -0.854 & 0.186 & 0.117 & -0.557 & 0.400 & -0.526 & -0.745 & -0.651 & -0.531 & & & \\
\hline & 2017 & .672 & -0.515 & 0.479 & 0.127 & -1.079 & -0.394 & -0.475 & 0.145 & -0.287 & -0.805 & -0.387 & -0.386 & -0.466 & 0.191 & 0.479 & & & \\
\hline & 2018 & .134 & -0.202 & 0.251 & -0.181 & 1.223 & 0.301 & 0.285 & 080 & -0.143 & 0.433 & 0.319 & 0.316 & 0.559 & 0.574 & 0.409 & & & \\
\hline & 2019 & 0.045 & 0.246 & 0.023 & -0.166 & 0.743 & 0.625 & 1.044 & -0.251 & 0.313 & 0.928 & -0.332 & 0.596 & 0.652 & -0.115 & -0.357 & & & \\
\hline & & & & & & Matri & ( & bety & indice & $z_{i j}^{\prime}$ & efere & vector & & & & & & & \\
\hline & 2016 & 0.000 & 0.000 & 1.519 & 0.161 & 4.453 & 1.340 & 3.604 & 0.191 & 0.038 & 2.206 & 0.619 & 1.260 & 1.951 & 0.000 & 1.020 & 4.285 & \multirow{4}{*}{6.857} & 0.625 \\
\hline & 2017 & 2.056 & 0.971 & 0.000 & 0.095 & 5.300 & 1.038 & 2.307 & 0.157 & 0.360 & 3.003 & 0.000 & 0.965 & 1.249 & 0.709 & 0.000 & 4.267 & & 0.622 \\
\hline & 2018 & 0.803 & 0.451 & 0.052 & 0.000 & 0.000 & 0.105 & 0.577 & 0.029 & 0.208 & 0.245 & 0.498 & 0.079 & 0.009 & 1.501 & 0.005 & 2.136 & & 0.312 \\
\hline & 2019 & 0.514 & 0.050 & 0.208 & 0.000 & 0.230 & 0.000 & 0.000 & 0.000 & 0.000 & 0.000 & 0.003 & 0.000 & 0.000 & 0.287 & 0.699 & 1.411 & & 0.206 \\
\hline \multirow{3}{*}{ 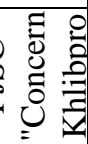 } & $\mathrm{W}_{\mathrm{j}}$ & 0.287 & 0.727 & 1.000 & 0.535 & 0.235 & 0.447 & 0.374 & 0.343 & 0.672 & 0.424 & 0.319 & 0.554 & 0.434 & 0.599 & 0.302 & & & \\
\hline & & \multicolumn{15}{|c|}{ Matrix of standardized values of indicators $\left(\mathrm{z}_{\mathrm{ij}}\right)$, adjusted by hierarchy ratio $\left(\mathrm{W}_{\mathrm{j}}\right): Z^{\prime}=\left\|z_{i j}^{\prime}\right\|$} & & & \\
\hline & 2016 & 0.438 & -1.216 & 1.229 & -0.624 & $\mathbf{0 . 2 7 7}$ & -0.154 & 0.505 & 0.531 & -0.554 & -0.038 & -0.198 & -0.259 & 0.061 & -0.649 & 0.455 & & & \\
\hline
\end{tabular}

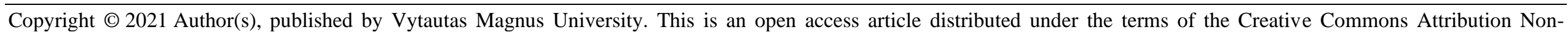

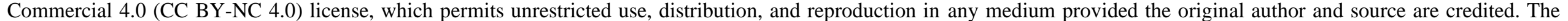
material cannot be used for commercial purposes. 
Yaryna Yuryk, Olena Bezpalko, Yuliia Hryniu

Effectiveness of Human Resources Management in The Enterprises of Ukraine's Bakery Industry

\begin{tabular}{|c|c|c|c|c|c|c|c|c|c|c|c|c|c|c|c|c|c|c|}
\hline 2017 & -0.124 & 0.479 & -1.557 & 0.841 & -0.081 & -0.602 & -0.065 & -0.076 & 1.015 & -0.537 & -0.248 & 0.024 & -0.668 & 0.479 & -0.170 & & & \\
\hline 2018 & 0.034 & 0.626 & 0.246 & -0.221 & -0.342 & 0.126 & 0.101 & -0.028 & 0.197 & -0.075 & -0.099 & 0.870 & 0.061 & 0.705 & 0.069 & & & \\
\hline 2019 & -0.348 & 0.111 & 0.082 & 0.004 & 0.146 & 0.630 & -0.540 & $-\mathbf{- 0 . 4 2 7}$ & -0.658 & 0.650 & 0.545 & -0.635 & 0.546 & -0.536 & -0.354 & & & \\
\hline & \multicolumn{15}{|c|}{ Matrix of distances between indicators $z_{i j}^{l}$ and reference vector } & & & \\
\hline 2016 & 0.000 & 3.394 & 0.000 & 0.000 & 0.000 & 0.615 & 0.000 & 0.919 & 2.459 & 0.473 & 0.002 & 1.273 & 0.236 & 0.000 & 0.000 & 3.061 & \multirow{4}{*}{5.145} & 0.595 \\
\hline 2017 & 0.316 & 0.022 & 7.758 & 2.148 & 0.128 & 1.519 & 0.325 & 0.123 & 0.000 & 1.409 & 0.000 & 0.716 & 1.474 & 1.272 & 0.390 & 4.195 & & 0.815 \\
\hline 2018 & 0.164 & 0.000 & 0.966 & 0.162 & 0.383 & 0.254 & 0.163 & 0.160 & 0.668 & 0.526 & 0.022 & 0.000 & 0.236 & 1.832 & 0.149 & 2.384 & & 0.463 \\
\hline 2019 & 0.619 & 0.266 & 1.315 & 0.394 & 0.017 & 0.000 & 1.092 & 0.000 & 2.798 & 0.000 & 0.629 & 2.264 & 0.000 & 0.013 & 0.654 & 3.172 & & 0.616 \\
\hline
\end{tabular}

Note: symbols of the indicators are taken from Table 1; in the cells, coordinates of the reference vector are highlighted in bold 


\section{sciendo}

Management Theory and Studies for Rural Business and Infrastructure Development

eISSN 2345-0355. 2021. Vol. 43. No. 1: 137-150

Article DOI: https://doi.org/10.15544/mts.2021.12

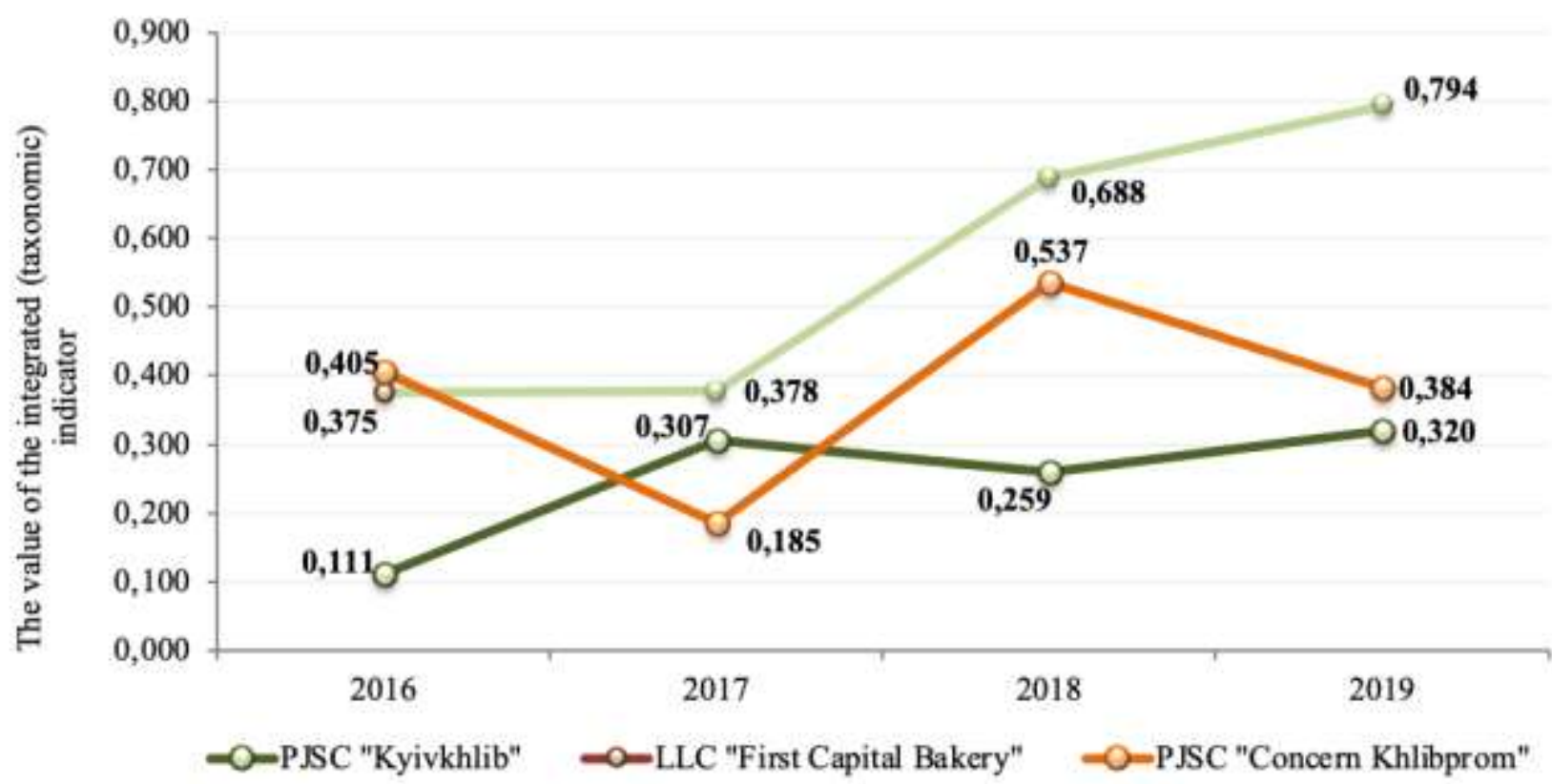

Figure 1. Dynamics of the integrated indicator of the effectiveness of human resources management at the companies in the sample

Of the three companies, only the First Capital Bakery LLC demonstrates a stable trend and strategic intentions to increase the effectiveness of its HR management: the company's Iehrm has grown annually and has moved from medium to high level. This can be partly explained by the "newcomer effect": the company is relatively recent on the market, it was built virtually "from scratch" in terms of technology (in terms of investment, the bakery's project of reconstruction and redevelopment has no analogues in Ukraine).

This gave the company a head starts both in the form of more comfortable and safe working conditions (compared to the competitors who need pretty much logistics renewal), and in terms of team building (usually, HR-management models of the "new formation" are characterized by flexibility and humanistic approach, as opposed to reactive (sometimes - passive) and technocratic approaches shaped in the post-Soviet period). In combination with an aggressive sales policy and sometimes the flagship range of products, the First Capital Bakery LLC has higher profits than competitors and reinvests them in expanding and qualitative transformation of its human capital, which is confirmed by the outcome data: almost all its incentive HR-metrics are higher, and those disincentives are lower than in other sampled companies. However, the bakery should pay attention to the work on training managers in the personnel reserve, which is found to be the company's most problematic and, moreover, its priority metric $\left(\mathrm{R}_{\mathrm{emt}}\right)$.

Iehrm PJSC "Kyivkhlib" is unstably balancing within the lower range of values, and PJSC "Concern Khlibprom" - mostly within the average range with a downward trend by the end of the study period. Therefore, the HR-strategy of PJSC "Kyivkhlib" should be directed towards a reengineering of personnel development and its harmonization with the company's operational needs. And the first steps have already been taken: in 2018, the bakery received certificates of quality management

Copyright (C) 2021 Author(s), published by Vytautas Magnus University. This is an open access article distributed under the terms of the Creative Commons Attribution Non-Commercial 4.0 (CC BY-NC 4.0) license, which permits unrestricted use, distribution, and reproduction in any medium provided the original author and source are credited. The material cannot be used for commercial purposes. 
system ISO 9001, whose results, by our assumption, affected the company's system of human resources management, because in 2019 its $\mathrm{I}_{\text {ehrm }}$ is the maximum value for the 4 years of evaluation. At PJSC Concern Khlibprom, efforts should be focused on the weak aspects of HR management, namely, the uncompetitive wages, which are presently the main productivity (profitability) disincentives, and low involvement of personnel in re training programs.

\section{Conclusions}

Research has found that Ukraine's industrial sector today has the highest percentage of unfilled vacancies and outflow of labor to visa-free EU countries, above all, of skilled personnel in worker and technical specialties as the main categories of the manufacturing companies' staff. Ignoring or insufficient awareness of their managers of the need to assess the effectiveness of human resource management will lead to informational vacuum and inability to respond quickly to internal and external personnel risks, especially during turbulence on the domestic labor market. This poses a real threat to the staffing of manufacturing enterprises, which entails a decline in economic activities in a number of sectors producing vital products for the population, in particular, in the bakery sector.

Among the existing methodological approaches to such an assessment, such as profit based, cost-oriented, stakeholder, comprehensive and benchmarking ones - the authors chose the penultimate one. The method of comprehensive assessment of HRmanagement effectiveness proposed in the article differs from others by the unified method of grouping and selection of HRmetrics according to the instructions of the international standard ISO 30414:2018, while the taxonomic method of their aggregation allowed us to reveal priority HRM-areas, and their degrees of difficulty and derive the outcome indicator for three largest regional employers in Ukrainian bakery sector. According to the size and dynamics of the integrated indicator of HR management effectiveness in 2016-2019, PJSC Kyivkhlib has been provided with recommendations within the anti-crisis HR strategy (conducting a personnel audit to identify of ways to save costs to keep of the company's staff, development and implementation of programs to combat staff turnover, which is one of the reasons for the stable reducing of the level of the company's personnel profitability), First Capital Bakery LLC - within the strategies to strengthen its position in the labor market by improving the work with the reserve of management personnel (development of mentoring, coaching support, monitoring the progress of "reservists" and adjusting plans for their personal promotion), and PJSC Concern Khlibprom - within the HRM focusing strategies (salary benchmarking, use of progressive methods to assess the level of professional competence of employees and its implementation on a regular basis to identify real needs for their training and retraining, optimizing the company's budget for programs of professional training).

\section{References}

Armstrong, M., Taylor, S. (2014). Armstrong's handbook of human resource management practice $\left(13^{\text {th }}\right.$ Edition). - London, Philadelphia: Kogan Page. 800 p.

Becker, G. S. (1975). Human Capital: A Theoretical and Empirical Analysis, with Special Reference to Education (Second Edition). - National Bureau of Economic Research. 268 p.

Becker, B. E., Huselid, M. A., Ulrich D. (2001). The HR Scorecard: Linking People, Strategy and Performance ( $1^{\text {st }}$ Edition). - Boston, MA: Harvard Business School Press. 234 p.

Bolotova, O.O. (2019). Metodichnij pidhid shhodo ocinki efektivnosti menedzhmentu personalu pidpriemstva // Visnik HNTU. No. 4 (71): P. 125-130. - https://doi.org/10.35546/kntu2078-4481.2019.4.14 [2020 04 24].

Boudlaie, H., Mahdiraji, H.A., Shamsi, S., Jafari-Sadeghi, V., Garcia-Perez, A. (2020). Designing a human resource scorecard: An empirical stakeholder-based study with a company culture perspective // Journal of Entrepreneurship, Management and Innovation. Vol. 16. No. 4: 113-147. - https://doi.org/10.7341/20201644 [2020 12 29]. 


\title{
sciendo
}

\author{
Management Theory and Studies for Rural Business and Infrastructure Development \\ eISSN 2345-0355. 2021. Vol. 43. No. 1: 137-150 \\ Article DOI: https://doi.org/10.15544/mts.2021.12
}

Carter, A., Hirsh, W., Mercer, M., Reilly, P. (2011). Obtaining Customer Feedback on HR: Finding out what managers and employees think of HR services and the HR function. - Institute for Employment Studies (IES), Sovereign House, Church Street, Brighton BN1 1UJ UK. 88 p.

Deloitte (2016). Enabling business results with HR "Measures that matter". https://www2.deloitte.com/content/dam/Deloitte/us/Documents/human-capital/us-hc-enabling-business-results-with-hrmeasures-that-matter.pdf [2020 12 29].

Deloitte Global Human Capital Trends (2020). The social enterprise at work: Paradox as a path forward. 124 p. https://www2.deloitte.com/content/dam/Deloitte/at/Documents/human-capital/at-hc-trends-2020.pdf [2020 12 29].

Dibernardino, F.J. (2015). IHR - Workforce Planning and Analytic. Optimize Human Capital Investments: Make the "Hard" Business Case. Vienna human capital Advisors. 37 p.

Dovgan, LE, Mokhonko, GA, Dudukalo, GO (2015). Efektivnist' upravlinnja personalom pidpriemstv: diagnostika ta mehanizm zabezpechennja: monografija. NTUU "KPI" (FMM).

Drucker, P. F. (1954). The practice of management ( $1^{\text {st }}$ Edition $) .-$ New York: Harper. 404 p.

Eurostat (2019). News release. First residence permits issued in the EU Member States remain above 3 million in 2018. 164/2019 - 25 October 2019. - https://ec.europa.eu/eurostat/documents/2995521/10189082/3-25102019-APEN.pdf [2020 04 23].

Fitz-enz, J. (1984). How to measure human resource management? - Saratoga Institute, McGraw Hill Book Co., 1984. $237 \mathrm{p}$

Fitz-enz, J. (1995). SHRM/ Saratoga Institute Human Resource Effectiveness Survey: 1994 Annual Report. Saratoga, CA: Saratoga Institute.

Fitz-enz, J. (2000). The ROI of Human Capital: Measuring the Economic Value of Employee Performance. AMACOM. Broadway, New York. 312 p.

Fitz-enz, J. (2010). The New HR Analytics: Predicting Economic Value of Your Company's Human Capital Investments. - AMACOM. Broadway, New York. 368 p.

Food Drink Europe (2019). Data \& Trends. EU Food \& Drinks Industry 2019 Report. https://www.fooddrinkeurope.eu/publication/data-trends-of-the-european-food-and-drink-industry-2019 [2020 0424 ].

Freeman, R E. (1984). Strategic management: A stakeholder approach. - Boston: Pitman. 276 p.

Gabanova, I. (2012). Human Resources Key Performance Indicators // Journal of Competitiveness. Vol. 4. No. 1: 117-128. - https://doi:10.7441/joc.2012.01.09 [2020 12 29].

Greenwood, M. (2002). Ethics and HRM: A Review and Conceptual Analysis // Journal of Business Ethics. Vol. 36. No. 3: 261-279.

Harrington, E. C. (1965). The Desirability Function // Industrial Quality Control. Vol. 21. No. 10: 494-498.

Hellwig, Z. (1968). Zastosowanie metody taksonomicznej do typologicznego podziału krajów ze względu na poziom ich rozwoju oraz zasoby i strukturę wykwalifikowanych kadr // Przegląd Statystyczny. Nr. 4: 307 - 326.

Huselid, M. A., Barnes, J. E. (2003). Human capital measurement systems as a source of competitive advantage. Working paper. - Harvard Business School, Boston. 27 p.

Kaplan, R. S., Norton, D. P. (1996). Using the balanced scorecard as a strategic management system // Harvard Business Review. Vol. 74. No. 1: 75-85. - https://doi:10.1016/S0840-4704(10)60668-0 [2020 0424$].$

Mitchell, R. K, Agle, B. R, Wood, D. J. (1997). Towards a Theory of Stakeholder Identification and Salience:

Defining the Principle of Who and What Really Counts // Academy of Management Review. Vol. 22. No. 4: 853-886.

Organisation Internationale de Normalisation, ISO. (2018). ISO 30414:2018. Human resource management -

Guidelines for internal and external human capital reporting. - https://www.iso.org/obp/ui/\#iso:std:iso:30414:ed1:v1:en [2020 04 28].

Quang, L.H., Thanh, T.T., Tan K. H., Tuyet A.T., Thuy L. Le T. (2020). Comparative significance of human resource management practices on banking financial performance with analytic hierarchy process // Growing Science. Vol. 6. No. 7: 1323-1328. - https:doi.org/10.1080/09720502.2017.1358874 [2020 12 29].

Phillips, J. J., Stone, R. D., Phillips, P. P. (2001). The Human Resources Scorecard: Measuring the Return on Investment. - Woburn, MA: Butterworth-Heinemann. 518 p.

Phillips, J. J., Phillips, P. P., Ray, R. (2016). Measuring the Success of Employee Engagement: A Step-by-Step Guide for Measuring Impact and Calculating ROI. Association for Talent Development. Alexandria, VA 22314 USA. $224 \mathrm{p}$.

Pluta, W. (1979). Metody wielowymiarowej analizy porównawczej w modelowaniu infomwcj i ekonomicznej kombinatu przemysłowego. - Wrocław. $156 \mathrm{~s}$.

Copyright (C) 2021 Author(s), published by Vytautas Magnus University. This is an open access article distributed under the terms of the Creative Commons Attribution Non-Commercial 4.0 (CC BY-NC 4.0) license, which permits unrestricted use, distribution, and reproduction in any medium provided the original author and source are credited. The material cannot be used for commercial purposes. 
PricewaterhouseCoopers (2014). A global study "Adapt to survive: how better alignment between talent and opportunity can drive economic growth". Commissioned by LinkedIn. 29 p. https://www.pwcavocats.com/fr/assets/files/pdf/2014/04/pwc_adapttosurvive_hrs_2014.pdf [2020 12 29].

Ptoukha Institute for Demography and Social Studies of the National Academy of Sciences of Ukraine. Population forecast for Ukraine until 2061 (2014). - https://www.idss.org.ua/public\# [2020 04 23].

Scarbrough, H., Elias, J. (2004). Evaluating Human Capital. Research Report. Chartered Institute of Personnel and Development. - CIPD House, Camp Road, London. 73 p.

Schneider, B., White, S. (2004). Service quality: Research perspectives. - Thousand Oaks, CA: Sage. 185 p.

Shvets, I.B., Kovalenko, T.V. (2013). Kompleksna ocinka jakosti upravlinnja personalom: monografija. Donetsk: DonNTU. 159 p.

Society for Human Resource Management (2017). Performance management that makes a difference: an evidence-based approach. Science-to-practice series. Printed in the United States of America. 49 p. https://www.shrm.org/hr-today/trends-and-forecasting/special-reports-and-expert-

views/documents/performance\%20management.pdf [2020 12 29].

State Statistics Service of Ukraine. Employed population by economic activity for 2000-2018 http://www.ukrstat.gov.ua.

Stock Market Infrastructure Development Agency (SMIDA): website - https:// smida.gov.ua [2020 05 04].

Ulrich, D. (1989). Assessing human resource effectiveness: Stakeholder, utility \& relationship approaches // Human Resource Planning. Vol. 12. No. 4: 301-315.

United Nations, Department of Economic and Social Affairs (DESA), Population Division. (2019). World Population Prospects 2019. - https://reliefweb.int/sites/reliefweb.int/files/resources/WPP2019_Highlights.pdf [2020 04 $23]$.

Viljoen, H.H. (2012). Human Capital Return-on-Investment (HCROI) in South African Companies listed on the Johannesburg Stock Exchange (JSE). Stellenbosch University. 216 p. 